\title{
HUBUNGAN ANTARA PEMENUHAN KEBUTUHAN ISTIRAHAT TIDUR DENGAN KEJADIAN HIPERTENSI PADA MASYARAKAT DI DUSUN CELEP KIDUL KELURAHAN DAGEN KECAMATAN JATEN KARANGANYAR
}

\author{
Wiwin Winarni ${ }^{1}$ Pradian Yoga Hartanto ${ }^{2}$
}

\begin{abstract}
Sleep is a period of time which is needed for human body to repair the organ cells and body system in order to work optimally. Based on the preface study conducted by the reseacher, some peoples in Celep Kidul have been suffered from hypertension. When interview was conducted, they mentioned that their time for sleeping less than 7 hours per day. The purpose of this study was to analyze the correlation between sleep needs with the incidence of hypertension of peoples in Celep Kidul.

The subject who used was peoples in Celep Kidul. This research used analytic with correlation design. The total population involved in this research were 65 peoples of Celep Kidul region. Depend on Krecjie table, the total samples involved were 56 peoples. Sampling technik used was purposive sampling. Data was collected by using quessionairres and measuring blood preasure of the peoples to collect data of hypertension. The data was analyzed by using chi square statistic.

There were two main results of this study : 1) The majority peoples of Celep Kidul showed that they had abnormal data of sleep needs was $73,21 \%$. 2) The total number of respondens who suffered from hypertension was $71,42 \%$. It can be concluded that the sleep needs has related to incidence of hypertension of peoples in Celep Kidul region $(p=0,013)$.
\end{abstract}

Keywords: sleep needs, hypertension

\section{PENDAHULUAN}

Hipertensi adalah keadaan darah yang sama atau melebihi $140 \mathrm{mmHg}$ sistolik dan atau melebihi $90 \mathrm{mmHg}$ diastolik pada seseorang yang tidak sedang makan obat antihipertensi. Klasifikasi berdasarkan hasil ratarata pengukuran tekanan darah yang dilakukan minimal dua kali tiap kunjungan pada dua kali kunjungan atau lebih dengan menggunakan cuff yang meliputi minimal $80 \%$ lengan atas pada pasien dengan posisi duduk dan telah beristirahat lima menit. (Rani, ed., et al., 2006)

Menurut JNC $\mathrm{VI}$, sebagaimana dikutip oleh Brashers (2007), diperkirakan bahwa 50 juta orang Amerika Serikat menderita Hipertensi. Orang Amerika keturunan Afrika cenderung menderita hipertensi lebih berat pada usia lebih dini dan memiliki risiko menderita stroke dan infark miokard (MI) dua kali lebih besar dibanding orang kulit putih. Populasi lansia cenderung menderita hipertensi sistolik lebih tersendiri, yang secara jelas berkaitan dengan peningkatan risiko $\mathrm{Ml}$ dan stroke. Pemahaman pasien dan kemampuan penatalaksanaan pasien masih sangat rendah. Faktor risiko dari hipertensi meliputi usia, obesitas, gaya hidup nyaman (kurang gerak), riwayat keluarga, merokok, alkohol, asupan natrium tinggi (terutama pada orang Amerika keturunan Afrika, lansia, dan penderita Diabetes), dan asupan kalium atau magnesium rendah (terutama pada orang Amerika keturunan Afrika).

Menurut Depkes RI (2012), sebagaimana dikutip oleh Asmarita (2014), sebagian besar kasus 
tekanan darah tinggi di masyarakat belum terdiagnosis. Di Indonesia, pada usia lebih dari atau sama dengan 18 tahun didapatkan prevalensi tekanan darah tinggi sebesar $31,7 \%$, yang sudah mengetahui memiliki tekanan darah tinggi hanya $7,2 \%$ dan yang minum obat hipertensi hanya $0,4 \%$.

Tidur adalah kesempatan bagi tubuh untuk memperbaiki sel-sel organorgan dan sistem tubuh agar bekerja lebih prima. Tidur bermanfaat bagi kesehatan fisik, antara lain pada saat tidur terjadi pertumbuhan sel-sel tubuh dan mengganti sistem kekebalan dan untuk kesehatan mental, tidur yang cukup memungkinkan aspek kejiwaan dan pikiran berkembang serta bekerja optimal. (Hasan, 2010) The National Sleep Foundation, Amerika Serikat, menyebutkan bahwa orang dewasa, membutuhkan sekitar $30 \%$ dari waktu 24 jam atau sekitar 7-9 jam untuk tidur. Jika kurang, mereka akan merasakan beberapa dampak yang tidak baik untuk kesehatan diantaranya dapat berpengaruh pada daya ingat, peningkatan tekanan darah dan konsentrasi. (Hasan, 2010)

Dusun Celep Kidul merupakan salah satu dusun yang berada di Kelurahan Dagen Kecamatan Jaten Karanganyar. Berdasarkan pemeriksaan tekanan darah yang dilakukan peneliti pada tanggal 22 November 2015 di Dusun Celep Kidul terhadap 30 orang laki-laki dewasa, didapatkan hasil 16 orang memiliki tekanan darah $\geq 140 / 90$ $\mathrm{mmHg}$. Hasil wawancara terhadap responden didapatkan bahwa mayoritas responden di Dusun Celep Kidul mempunyai kebiasaan tidur kurang dari 7 jam tiap malam. Responden sering merasakan pusing dan badannya pegal-pegal bila pulang terlarut malam, dan pada saat terbangun dari tidur merasa lemas. Selain itu, keluhan cepat lelah saat beraktivitas sering juga dirasakan. Selama ini belum pernah dilakukan penelitian apakah tekanan darah pada orang dewasa terkait dengan istirahat tidur yang kurang.

Berdasarkan uraian di atas maka peneliti tertarik melakukan penelitian tentang "Hubungan Pemenuhan Kebutuhan Istirahat Tidur dengan Kejadian Hipertensi pada Masyarakat di Dusun Celep Kidul Kelurahan Dagen Kecamatan Jaten Kabupaten Karanganyar".

\section{TUJUAN PENELITIAN}

1. Tujuan Umum

Untuk mengetahui hubungan antara pemenuhan kebutuhan istirahat tidur dengan kejadian hipertensi pada masyarakat di Dusun Celep Kidul Kelurahan Dagen, Jaten, Karanganyar.

2. Tujuan Khusus

a. Mengidentifikasi jumlah jam tidur pada masyarakat di Dusun Celep Kidul

b. Mengidentifikasi tekanan darah pada masyarakat di Dusun Celep Kidul.

\section{DESAIN PENELITIAN}

Penelitian ini merupakan bentuk penelitian analitik dengan desain korelasi untuk mengetahui hubungan antara kejadian hipertensi sebagai variabel bebas dan pemenuhan kebutuhan istirahat tidur sebagai variabel terikat. Pengumpulan data dilakukan dengan menggunakan kuesioner dan melakukan pengukuran tekanan darah. Analisa bivariat digunakan dalam penelitian ini adalah uji chisquare untuk mengetahui hubungan antara variabel bebas dan terikat.

\section{POPULASI, SAMPEL, DAN TEHNIK SAMPLING}

Populasi pada penelitian ini adalah seluruh masyarakat Dusun Celep Kidul berjenis kelamin laki-laki berjumlah 65 orang. Besar sampel yang ditetapkan peneliti adalah 56 
berdasarkan tabel KRECJIE. Teknik sampling yang peneliti gunakan adalah teknik purposive sampling yaitu pengambilan sampel didasarkan atas pertimbangan peneliti sendiri. (Hidayat, 2008)

\section{HASIL PENELITIAN}

Berdasarkan penelitian yang telah dilakukan bulan Februari 2016 didapatkan karakteristik responden berdasarkan usia dan jenis pekerjaan beserta hasil penelitian mengenai hubungan pemenuhan kebutuhan istirahat tidur dengan kejadian hipertensi, yaitu sebagai berikut :

Tabel 1. Distribusi Frekuensi Karakteristik Responden Berdasarkan Usia

\begin{tabular}{ccc}
\hline $\begin{array}{c}\text { Kelompok } \\
\text { usia }\end{array}$ & $\mathrm{f}$ & $\%$ \\
\hline $15-20$ & 12 & 21,42 \\
\hline $21-25$ & 14 & 25 \\
\hline $26-30$ & 15 & 26,78 \\
\hline $31-35$ & 3 & 5,35 \\
\hline $36-40$ & 12 & 21,42 \\
\hline Jumlah & 56 & 100 \\
\hline
\end{tabular}

Dari data di atas diperoleh informasi bahwa sebagian besar responden $(26,78 \%)$ berada pada kelompok umur 26-30 tahun dan jumlah responden paling sedikit (5,35\%) berada pada kelompok umur 31$35 \%$ tahun.

Tabel 2. Distribusi Frekuensi Karakteristik Responden

Berdasarkan Jenis Pekerjaan

\begin{tabular}{ccc}
\hline $\begin{array}{c}\text { Jenis } \\
\text { Pekerjaan }\end{array}$ & $f$ & $\%$ \\
\hline $\begin{array}{c}\text { Pegawai } \\
\text { swasta }\end{array}$ & 21 & 37,5 \\
\hline Petani/Buruh & 26 & 46,42 \\
\hline Pelajar & 9 & 16,07 \\
\hline Jumlah & 56 & 100 \\
\hline
\end{tabular}

Dari data di atas diperoleh informasi bahwa sebagian besar responden bekerja sebagai petani/buruh sebanyak 26 responden (46,42\%) dan paling sedikit responden sebagai pelajar sebanyak 9 responden (16,07\%).
Tabel 3. Distribusi Frekuensi

Pemenuhan Kebutuhan Istirahat Tidur

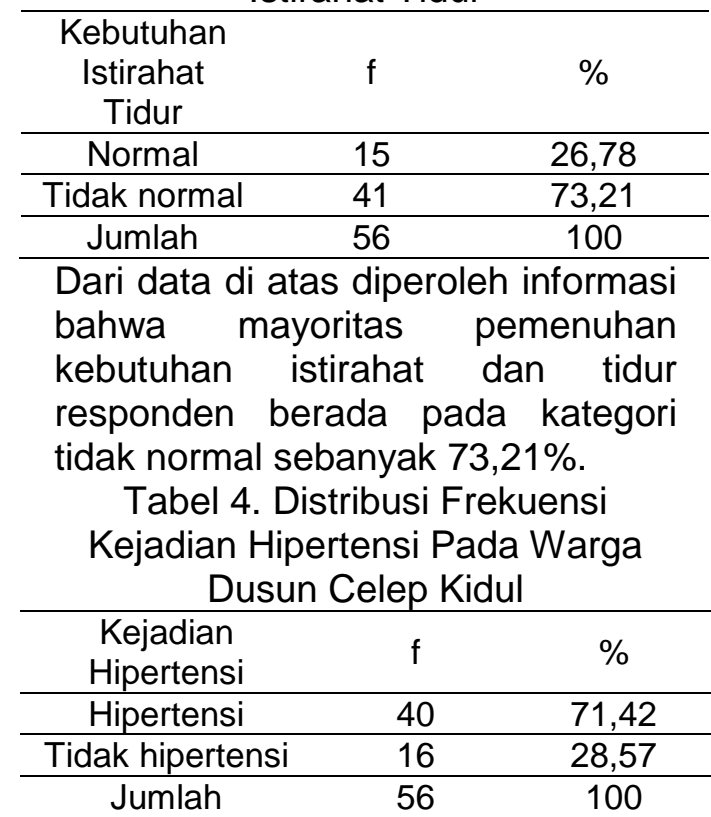

Dari data di atas diperoleh informasi bahwa sebagian besar responden mengalami hipertensi sebanyak 40 responden $(71,42 \%)$.

Tabel 5. Tabulasi Silang Hubungan Pemenuhan Kebutuhan Istirahat Tidur dengan Kejadian Hipertensi

\begin{tabular}{|c|c|c|c|}
\hline $\begin{array}{c}\text { Jumlah } \\
\text { Jam } \\
\text { tidur }\end{array}$ & Hipertensi & $\begin{array}{c}\text { Tidak } \\
\text { hipertensi }\end{array}$ & $p$ \\
\hline Normal & 7 & 8 & \\
\hline $\begin{array}{l}\text { Tidak } \\
\text { normal }\end{array}$ & 33 & 8 & 0,013 \\
\hline
\end{tabular}

Dari data di atas diperoleh informasi bahwa jumlah warga yang mengalami hipertensi dengan jumlah jam tidur yang tidak normal sebanyak 33 responden. Hasil analisa dengan menggunakan uji chi square menunjukkan nilai $p$ sebesar 0,013 . Karena nilai $p<0,05$ maka dapat disimpulkan bahwa terdapat hubungan antara pemenuhan kebutuhan istirahat tidur dengan kejadian hipertensi.

\section{PEMBAHASAN}

1. Pemenuhan kebutuhan istirahat tidur pada masyarakat di Dusun Celep Kidul 
Berdasarkan data yang disajikan dalam tabel 3 dapat diketahui bahwa sebagian besar warga di Dusun Celep Kidul mempunyai kebiasaan jumlah tidur yang tidak normal sebanyak 41 responden $(73,21 \%)$. Rata-rata pemenuhan kebutuhan istirahat dan tidur dalam satu hari kurang dari 7-9 jam/hari.

Tarwoto dan Wartonah (2015) mendefiniskan istirahat sebagai suatu keadaan dimana kegiatan jasmaniah menurun yang berakibat badan menjadi lebih segar. Tidur adalah suatu kegiatan relatif tanpa sadar yang penuh ketenangan tanpa kegiatan yang merupakan urutan siklus yang berulang-ulang dan masing-masing menyatakan fase kegiatan otak dan badaniah yang berbeda.

Berdasarkan tingkat perkembangannya, jumlah kebutuhan tidur manusia masa dewasa yaitu usia 18-40 tahun adalah 7-9 jam/hari. Mubarak, Indrawati dan Susanto (2015) menjelaskan bahwa salah satu faktor yang dapat mempengaruhi kuantitas dan kualitas tidur adalah faktor kelelahan. Jika seseorang semakin lelah maka siklus tidur REM yang dilaluinya akan semakin pendek. Tahapan tidur REM pada orang dewasa normalnya $20-25 \%$ dari jumlah jam tidur pada malam hari. Jika siklus tidur REM memendek maka jumlah jam tidur pada malam hari akan berkurang. Hal ini sesuai dengan data yang didapatkan bahwa mayoritas warga mempunyai jumlah jam tidur yang kurang. Data pada tabel 2 menunjukkan bahwa sebanyak 46,42\% warga Dusun Celep Kidul bekerja sebagai petani/buruh. Hasil wawancara terhadap beberapa responden menyebutkan bahwa pekerjaan yang dilakukan setiap hari sering membuat tubuhnya menjadi kelelahan. Hal ini menyebabkan beberapa warga mengalami kesulitan tidur.

2. Kejadian hipertensi pada masyarakat di Dusun Celep Kidul Berdasarkan data yang disajikan dalam tabel 4 didapatkan bahwa sebanyak 40 warga $(71,42 \%)$ mengalami hipertensi saat dilakukan pengukuran tekanan darah. Hasil pengukuran tekanan darah saat pengumpulan data didapatkan tekanan darah warga yang mengalami hipertensi berada pada rentang 140/90 mmHg sampai dengan 180/100 mmHg. Menurut WHO (2011), sebagaimana dikutip oleh Asmarita (2014), batas normal tekanan darah adalah kurang dari atau $120 \mathrm{mmHg}$ tekanan sistolik dan kurang dari atau $80 \mathrm{mmHg}$ tekanan diastolik. Seseorang dinyatakan mengidap hipertensi bila tekanan darahnya lebih dari 140/90 mmHg.

Hasil wawancara terhadap beberapa warga menyebutkan sering mengeluh tidak bisa tidur, nyeri kepala dan terasa kaku pada leher. Hal ini sesuai dengan penjelasan dari Muwarni (2011), tanda dan gejala dari hipertensi dapat berupa perasaan capek, mudah tersinggung, insomnia, pusing dan sakit kepala pada bagian tengkuk.

3. Hubungan pemenuhan kebutuhan istirahat tidur dengan kejadian hipertensi pada masyarakat di Dusun Celep Kidul Hasil analisa statistik dengan menggunakan uji chi square seperti dapat dilihat pada tabel 5 didapatkan nilai $p=0,013$, karena $p<0,05$ dapat disimpulkan bahwa terdapat hubungan antara pemenuhan kebutuhan istirahat tidur dengan kejadian hipertensi. Hasil penelitian ini sesuai dengan hasil penelitian yang dilakukan oleh Asmarita (2014) terhadap 36 
pasien hipertensi di RSUD Karanganyar, yang menunjukkan adanya hubungan kualitas tidur dengan kejadian hipertensi.

Hasil wawancara terhadap beberapa warga Dusun Celep Kidul menyebutkan bahwa sebagian besar warga sering merasa kelelahan akibat bekerja. Data pada tabel 2 menunjukkan bahwa sebanyak $46,42 \%$ warga Dusun Celep Kidul bekerja sebagai petani/buruh. Mubarak, Indrawati dan Susanto (2015) menyebutkan bahwa kelelahan yang berlebihan dapat mengakibatkan seseorang mengalami kesulitan tidur dan memicu terjadinya stres. Gejala fisiologis yang diakibatkan karena kurang tidur anatara lain kekakuan motorik halus, penurunan reflek, waktu respon melambat, penurunan kewaspadaan visual dan aritmia jantung. Sedangkan gejala psikologis yang muncul dapat berupa kebingungan, disorientasi, peningkatan sensitivitas terhadap nyeri, cepat marah, apatis, agitasi, hiperaktif dan penurunan motivasi. Hal ini sesuai dengan penjelasan dari Baradero dan Yakobus (2008) yang menyebutkan beberapa faktor risiko hipertensi esensial meliputi umur, jenis kelamin (pria), riwayat keluarga mengalami hipertensi, obesitas, merokok, kadar garam tinggi, konsumsi alkohol dan stres emosi yang merangsang sistem saraf simpatis. Apabila sistem saraf simpatis dirangsang, katekolamin seperti epinefrin dan noreepinefrin akan dikeluarkan. Kedua zat kimia ini menyebabkan konstriksi pembuluh darah, meningkatnya curah jantung dan kekuatan kontraksi ventrikel.

Smeltzer dan Bare (2002) sebagaimana dikutip oleh Aspiani (2014) menjelaskan bahwa mekanisme yang mengontrol konstriksi dan relaksasi pembuluh darah terletak di pusat vasomotor pada medula di otak. Dari pusat vasomotor ini bermula jaras saraf simpatis yang berlanjut ke bawah korda spinalis dan keluar dari kolumna medula spinalis ke ganglia simpatis di toraks dan abdomen. Rangsangan pusat vasomotor dihantarkan dalam bentuk impuls yang bergerak ke bawah melalui sistem saraf simpatis ke ganglia simpatis. Pada titik ini, neuron pre ganglion melepaskan asetilkolin yang akan merangsang serabut saraf pasca ganglion ke pembuluh darah, dimana dengan dilepaskannya norepinefrin mengakibatkan konstriksi pembuluh darah.

Pada saat bersamaan ketika sistem saraf simpatis merangsang pembuluh darah sebagai respon rangsang emosi, kelenjar adrenal juga terangsang mengakibatkan tambahan aktivitas vasokontriksi. Medula adrenal menyekresi epinefrin yang menyebabkan vasokonstriksi. Korteks adrenal menyekresi kortisol dan steroid lainnya, yang dapat memperkuat respon vasokonstriktor pembuluh darah. Vasokonstriksi yang mengakibatkan penurunan aliran darah ke ginjal menyebabkan pelepasan renin.

Renin yang dilepaskan merangsang pembentukan Angiotensin I yang kemudian diubah menjadi Angiotensin II, vasokonstriktor kuat, yang pada akhirnya merangsang sekresi aldosteron oleh korteks adrenal. Hormon ini menyebabkan retensi natrium dan air oleh tubulus ginjal, menyebabkan peningkatan volume intravaskuler. Faktorfaktor tersebut mencetuskan terjadinya hipertensi. 
Pada penelitian ini responden yang digunakan berada pada rentang usia 18-40 tahun dan ditemukan kejadian hipertensi pada rentang usia tersebut. Hal ini tidak sesuai dengan teori yang disampaikan oleh Muwarni (2011) yang menyebutkan bahwa salah satu faktor risiko hipertensi adalah usia. Laki-laki dengan usia lebih dari 55 tahun beresiko mengalami hipertensi. Dari perbedaan temuan tersebut dapat diketahui bahwa pada usia yang lebih muda juga dapat ditemukan kejadian hipertensi. Hal ini sesuai dengan penjelasan dari Hasan (2010) yang menyebutkan bahwa orang yang mengalami kurang tidur berisiko dua kali lebih besar cepat meninggal dibandingkan seseorang yang memiliki penyakit jantung. Lebih lanjut para peneliti mengungkapkan, kekurangan tidur memiliki kaitan erat dengan peningkatan tekanan darah. Artinya, kurang tidur akan meningkatkan risiko seseorang terkena stroke dan serangan jantung. Menurut Kozier, et al. (2010), tidur memberi pengaruh fisiologis pada sistem saraf dan tubuh lain. Tidur juga dapat memulihkan tingkat aktivitas normal dan keseimbangan normal diantara bagian sistem saraf. Tidur juga penting untuk sintesis protein, yang memungkinkan proses perbaikan. Peran tidur dalam kesejahteraan psikologis paling terlihat dengan memburuknya fungsi pemikiran akibat tidak tidur. Individu dengan jumlah jam tidur yang tidak cukup cenderung menjadi mudah marah secara emosional, memiliki konsentrasi yang buruk,dan mengalami kesulitan dalam membuat keputusan.

Berdasarkan teori tersebut dapat disimpulkan bahwa pemenuhan kebutuhan istirahat tidur berhubungan dengan kejadian hipertensi.

\section{KESIMPULAN}

1. Mayoritas pemenuhan kebutuhan istirahat dan tidur masyarakat di Dusun Celep Kidul, Jaten, Karanganyar berada pada kategori tidak normal sebanyak $73,21 \%$.

2. Kejadian hipertensi pada warga di Dusun Celep Kidul mengalami ditemukan sebanyak $71,42 \%$.

3. Pemenuhan kebutuhan istirahat dan tidur mempunyai hubungan dengan kejadian hipertensi pada masyarakat di Dusun Celep Kidul. Hal ini ditunjukkan dengan hasil analisa statistik dengan menggunakan chi-square menunjukkan nilai $p=0,013$.

\section{SARAN}

1. Masyarakat Dusun Celep Kidul perlu meningkatkan pemenuhan kebutuhan istirahat dan tidur. Hal ini dapat dilakukan dengan meningkatkan jumlah jam tidur per hari.

2. Perlu dilakukan penelitian mengenai faktor-faktor yang mempengaruhi pemenuhan kebutuhan istirahat tidur sehingga dapat digunakan untuk memperbaiki kebiasaan tidur warga.

\section{DAFTAR PUSTAKA}

Asmarita, I. 2014. Hubungan Antara Kualitas Tidur dengan Tekanan Darah pada Pasien Hipertensi di Rumah Sakit Daerah Umum Karanganyar. Tesis Pascasarjana. UMS, Surakarta.

Aspiani, R.Y. 2014. Buku Ajar Asuhan Keperawatan Klien Gangguan Kardiovaskuler aplikasi NIC \& NOC. EGC, Jakarta.

Brashers, V. 2007. Aplikasi Klinis Patofisiologi. Edisi II. Alih 
Bahasa H.Y Kuncara. EGC, Jakarta.

Baradero, M.W.D. dan Yakobus S. 2008. Klien Gangguan Kardiovaskuler : Seri Asuhan Keperawatan. EGC, Jakarta.

Hidayat, A.A.A. 2008. Riset Keperawatan dan Teknik Penulisan IImiah. Salemba Medika, Jakarta.

Hasan, A.F. 2010. Rahasia Umur 100 Tahun. Buku Kita, Yogyakarta.

2010. The Power of Tidur.

Mutiara Media, Yogayakarta.

Kozier, Barbara, et al., 2010. Buku Ajar Fundamental Keperawatan Konsep, Proses, dan Praktik. Volume 2. EGC, Jakarta.
Mubarak, W.I, Indrawati, L. dan Susanto, J. 2015. Buku Ajar IImu Keperawatan Dasar. Salemba Medika, Jakarta.

Murwani, A. 2011. Perawatan Pasien Penyakit Dalam. Gosyen Publishing, Yogyakarta.

Rani, A. ed., et al. 2006. Panduan Pelayanan Medik. Fakultas Kedokteran Universitas.

Tarwoto dan Wartonah. 2015. Kebutuhan Dasar Manusia dan Proses Keperawatan. Edisi 5. Salemba Medika, Jakarta.

${ }^{1}$ Dosen Akper Panti Kosala Surakarta

${ }^{2}$ Mahasiswa Akper Panti Kosala Surakarta 